\title{
Identification of Crucial Genetic Factors, Such as PPAR $\gamma$, that Regulate the Pathogenesis of Fatty Liver Disease in Dairy Cows Is Imperative for the Sustainable Development of Dairy Industry
}

\author{
Kerong Shi *(D, Ranran Li, Zhongjin Xu and Qin Zhang \\ Key Laboratory of Animal Bioengineering and Disease Prevention, College of Animal Science and Technology, \\ Shandong Agricultural University, Tai'an 271018, Shandong, China; liranranone@163.com (R.L.); \\ 18206381011@139.com (Z.X.); qzhang@cau.edu.cn (Q.Z.) \\ * Correspondence: krshi@sdau.edu.cn
}

Received: 27 February 2020; Accepted: 1 April 2020; Published: 7 April 2020

check for updates

Simple Summary: Fatty liver disease frequently occurs in dairy cows, a typical type of non-alcoholic fatty liver disease (NAFLD), resulting in a high culling rate of dairy cows during the perinatal period because of limitations of lactation and reproduction performance of cows with subsequent complications. This has been developing into a worldwide crucial industrial problem. Studies about NAFLD have shown that PPAR $\gamma$ (peroxisome proliferator-activated receptor $\gamma$ ) participates or regulates the fat deposition in liver by affecting the biological processes of hepatic lipid metabolism, insulin resistance, gluconeogenesis, oxidative stress, and inflammation, which all contribute to fatty liver. This review mainly focuses on the understanding of molecular pathogenesis of fatty liver disease in dairy cows by taking PPAR $\gamma$ as an example, so as to provide important information for discovering critical therapeutic targets, such as PPAR $\gamma$, for fatty liver disease, and contribute to breeding improvement of fatty liver disease-resistant dairy cattle and eventually sustainable development of dairy industry.

Abstract: Frequently occurring fatty liver disease in dairy cows during the perinatal period, a typical type of non-alcoholic fatty liver disease (NAFLD), results in worldwide high culling rates of dairy cows (averagely about $25 \%$ ) after calving. This has been developing into a critical industrial problem throughout the world, because the metabolic disease severely affects the welfare and economic value of dairy cows. Findings about the molecular mechanisms how the fatty liver disease develops would help scientists to discover novel therapeutic targets for NAFLD. Studies have shown that PPAR $\gamma$ participates or regulates the fat deposition in liver by affecting the biological processes of hepatic lipid metabolism, insulin resistance, gluconeogenesis, oxidative stress, endoplasmic reticulum stress and inflammation, which all contribute to fatty liver. This review mainly focuses on crucial regulatory mechanisms of PPAR $\gamma$ regulating lipid deposition in the liver via direct and/or indirect pathways, suggesting that PPAR $\gamma$ might be a potential critical therapeutic target for fatty liver disease, however, it would be of our significant interest to reveal the pathology and pathogenesis of NAFLD by using dairy cows with fatty liver as an animal model. This review will provide a molecular mechanism basis for understanding the pathogenesis of NAFLD.

Keywords: dairy cows; PPAR $\gamma$; fatty liver; non-alcoholic fatty liver disease (NAFLD); genetic factor; dairy industry 


\section{Introduction}

Fatty liver syndrome, a typical type of metabolic disorder, frequently occurs in populations of dairy cows in commercial farms throughout the world, which is caused by negative nutrient balance after calving. High-yielding dairy cows, especially for cows with $30 \mathrm{~kg}$ of daily milk yield and more, are usually inclined to develop fatty liver syndrome in the early lactation period. There are more risk factors available to developing fatty liver syndrome, such as cows with high body condition score (BCS) and/or high body fat, feed intake decreases around calving, etc.

Our investigation in the last three years indicated that $48.85 \%$ of dairy cows $(n=346)$ within 2 weeks after parturition were diagnosed with light or severe fatty liver disease by randomly selecting 710 Holstein dairy cows from four commercial farms (Zhang et al., unpublished data) [1,2]. The suspected fatty liver cows and/or normal cows were firstly distinguished by applying the previously reported model [3] using the detected values of serum biochemical traits (glucose, Glu; non-esterified fatty acid, NEFA; aspartate transaminase, AST), then representative cows with different suspected extents were biopsied for liver tissue samples for fat deposition amount assessment by oil red staining. It is estimated that $40 \%-60 \%$ of high-yielding dairy cows (daily milk yield $>35 \mathrm{~kg}$ ) develop moderate to severe fatty liver disease within 2 weeks after calving [4]. Moreover, it is not uncommon for the two short weeks after parturition to account for $50 \%$ of morbidity on a dairy farm [5], which is in accordance with our results.

The perinatal disorders including fatty liver disease remain as prevalent now as they were 20 years ago [5], causing high culling rate of dairy cows in their early lactation period, which is becoming a critical concern in modern dairy industry. The average culling rate of dairy cows within 60 days of lactation (during parturition period) in populations is about $24 \%$ in USA [6-8], and about $27 \%$ in China $[9,10]$. In clinical practice, increasing blood calcium levels and using anti-inflammatory drugs after delivery in dairy cows could reduce the incidence of this disease and/or decrease the economic loss [11]. However, these strategies cannot either completely change the situation or alleviate contradictions. The incidence of fatty liver disease at the early lactation not only decreases the milk yield of the coming lactation period, but also attenuates the future milk production and reproduction performance because of subsequent health problems of dairy herds $[1,2,7,12]$, such as ketosis, displaced abomasum, mastitis, etc. It is estimated that economic losses due to the treatment of and reduction in milk production by one dairy cow with ketosis accounts for 151-312 US dollars [11].

\section{Ethics Approval and Consent to Participate}

All the investigation and biopsy processes were carried out in accordance with guidelines issued by the Shandong Agricultural University Animal Care and Use Committee (approval number, SDAUA-2017-044). We have obtained written informed consent from the animal owner to use these animals in the study.

\section{Progress of the Pathogenesis Mechanism of Fatty Liver Disease}

The etiology of fatty liver in perinatal dairy cows primarily includes the negative nutrient balance and the accumulation of high level of free fatty acids (FFA) in serum or triglycerides (TAG) deposited in liver [1]. Liver, the central organ of organisms, regulates the metabolic balance of carbohydrate, fat, and protein in mammals [13]. After calving, the food intake of dairy cows further decreases, while lactation slowly increases. Thus, the body lactose consumption easily results in the cow to be susceptible to experiencing an insufficient sugar supply, thus promoting fat mobilization in the liver $[14,15]$. Additionally, energy and substance metabolism is centered in the liver. The increasing fat mobilization promotes gluconeogenesis, increases the blood sugar concentration, and alleviates the negative nutrient balance. At the same time, the enhanced fat mobilization promotes the dramatic increase of non-esterified fatty acid (NEFA) in the liver [16], which is partly re-esterified to synthesize the triglycerides (TAG), a type of very-low-density lipoprotein (VLDL), that is hardly transported out 
of the liver [17]. Especially for dairy cattle, TAG is excessively accumulated because of its lack for esterase, resulting in susceptibility to fatty liver disease [14,18].

As for non-alcoholic fatty liver disease (NAFLD) occurring in human beings, metabolic disorder syndromes and obesity are also usually the main causes, with increased plasma insulin and fatty acid concentration, elevated fasting aminotransferase (AST/ALT) and/or triglycerides (TAG) level, and also abnormal lipid accumulation in the liver [19-21]. In addition, another of the most important risk factors is histological evidence of hepatic inflammation [22] caused by acute inflammation and subacute inflammation [5]. Thus, dairy cows with fatty liver disease is a typical NAFLD animal model, good for revealing the pathology and pathogenesis of NAFLD.

In recent years, scientists have proposed a "two-hit" theory to explain the pathogenesis mechanisms of NAFLD [23,24]. (1) The "first hit" was caused by insulin resistance (IR). IR can not only strengthen lipolysis of surrounding tissues, but also causes hyperinsulinemia. The lipolysis of adipose tissue results in increased FFA and enhanced TAG synthesis in the liver. The FFA has hepatocellular toxicity, increasing the permeability of cell membrane and disrupting the mitochondrial function by inhibiting related enzymes. (2) The "second hit" was caused by the imbalance between the coexisting systems of oxidation and anti-oxidation in the liver. The increase in lipid peroxidation results in persistent reactive oxygen species (ROS) production. In addition to the pre-existing factors related to the enhanced oxygen stress, other new or additional factors can increase lipid peroxidation for a second hit to the liver, such as inflammatory cytokines, adipokines, endotoxins, and mitochondrial inactivation. The second hit will eventually lead to NASH (non-alcoholic steatohepatitis) progression beyond hepatic steatosis that promotes oxidative stress, inflammation, cell death, and fibrosis. Especially, the inflammation is positively correlated with liver injury and negatively correlated with lipolysis by inhibiting lipase activity, inhibiting the transport of lipoproteins and/or lipids and causing lipid deposition. Moreover, it also induces lipid peroxidation, IR, and cell apoptosis $[25,26]$, aggravating the pathogenesis of NAFLD. (3) Actually, there is even a "third hit" [27], which is cell death and irreversible cell repair of hepatocytes. (4) Additionally, endoplasmic reticulum (ER) stress is another important "hit" in the pathogenesis of NAFLD. The metabolic disorders, such as obesity and diabetes, can cause ER stress, leading to the accumulation of incorrectly folded proteins (unfolded protein response, UPR) and affecting the normal physiological functions of liver cells. It is worth mentioning that ER stress can activate SREBP (sterol-regulatory element binding protein), promoting the transcription of acetyl-CoA carboxylase (ACC) and fatty acid synthase (FAS), resulting in increased synthesis of TAG and fatty acids in the liver [28,29]. Moreover, the oxidative stress (ROS producing) in liver cells can induce ER stress leading to incorrect protein fold and/or protein modification. Additionally, ER stress also can be the cause of oxidative stress. The biological process of ER stress and oxidative stress interact each other through different pathways, leading to IR and aggravating the NAFLD [30-32].

However, the pathogenesis of NAFLD is still unclear. It was proposed that the abnormality in lipid and lipoprotein metabolism accompanied by chronic inflammation and oxidative stress is the central pathway and/or the major risk factors involved in the pathogenesis of NAFLD [33,34]. It is generally believed that the occurrence of fatty liver is not only closely related to insulin resistance and disorder of fat metabolism, but also related to biological processes, such as glycometabolism disorder, oxidative stress, and intracellular inflammatory response [23,35]. Moreover, these processes are correlated and/or coordinated with each other and accelerate the progress of NAFLD [23,36]. There are numerous factors involved in the pathogenesis of NAFLD. For example, PPAR $\alpha$ (peroxisome proliferator-activated receptor $\alpha$ ) and/or PPAR $\gamma$, microsomal triglyceride transport protein (MTP), apolipoprotein (apoB) play important roles in hepatic lipid metabolism, lipid transport, and secretion [35,37]; adipocytokines (Tumor necrosis factor, leptin, and adiponectin), cytokines (Interleukin-6, IL-6; glucagon-like peptide-1, GLP-1; fibroblast growth factor 19, FGF-19; fibroblast growth factor 21, FGF-21; growth-hormone-releasing hormone, GHRH; etc.), and toll-like receptors (TLRs) participate in insulin resistance (IR), oxidative stress, and inflammatory response, and mediate cell apoptosis/necrosis to promote liver fibrosis [35,38-40]; microRNAs (such as mir-107 and miR-103) 
are reported to regulate insulin resistance. Recently, RG-125 (also named AZD4076), the antagonist against microRNA-103/107, has entered the phase I clinical trial of NASH (non-alcoholic steatohepatitis) treatment [39].

Accordingly, the pathogenesis of NAFLD is usually related to abnormal hepatic lipid metabolism, gluconeogenesis, IR, oxidative stress, and inflammation [23,39-43]. The causal relationship and the underlying molecular mechanisms of these biological processes still remains unclear. However, the discovery of some important regulatory factors/genes that regulate all these biological processes would be helpful to reveal the molecular pathogenesis of NAFLD.

Recent studies have shown that PPAR $\gamma$ (peroxisome proliferator-activated receptor $\gamma$ ) participates or regulates lipid metabolism in the liver by affecting the biological processes of hepatic lipid metabolism, insulin resistance, gluconeogenesis, oxidative stress, and inflammation. In the following content, PPAR $\gamma$ will be taken as an example to elaborate the crucial regulatory role of certain critical genetic factors in the hepatic liver metabolism and therefore lipid deposition, via direct and/or indirect pathways. Rosiglitazone (RGZ) and other thiazolidinedione (TZD) synthetic ligands of PPAR $\gamma$ are insulin sensitizers that have been used for the treatment of type II diabetes [44]. As for the PPAR $\gamma$ related substances, apigenin, a food-derived compound, were reported significantly ameliorated NAFLD and obesity-induced metabolic syndrome by acting as a PPAR $\gamma$ modulator through Nrf2 (nuclear factor E2-related factor 2), inhibiting the lipid metabolism and oxidative stress abnormity $[45,46]$.

\section{Molecular Regulatory Effects of PPAR $\gamma$ on the Pathogenesis of Fatty Liver Disease}

PPARs are nuclear hormone receptors that belong to the steroid hormone superfamily, playing an important role in regulating various intracellular metabolic processes [47]. PPARs comprise of three subtypes (PPAR $\alpha, \operatorname{PPAR} \beta$, and PPAR $\gamma$ ) that are encoded by multiple genes [48,49]. PPAR $\alpha$, PPAR $\beta$, and PPAR $\gamma$ contain 468, 441, and 479 amino acid residues, respectively [50,51]. Although they are highly homologous regions regarding their similar amino acid sequence and protein structure, $\operatorname{PPAR} \alpha, \operatorname{PPAR} \beta$, and PPAR $\gamma$ exhibit different tissue expression specificity and selectivity for different ligands [52]. PPAR $\gamma$ is mainly expressed in adipose and immune tissues, with low expression in the liver, kidneys, and cartilage [53]. However, PPAR $\gamma$ is an important participant in lipid metabolism and lipogenesis [54,55] and significantly affects hepatic glucose and lipid metabolism, adipocyte differentiation, and inflammatory responses. Studies have shown that PPAR $\gamma$ is activated by peroxisome proliferators as well as endogenous fatty acids and their derivatives. In addition, PPAR $\gamma$ participates in lipid metabolism [48] via increasing the uptake and storage of lipids as TAG in adipose tissues and highly expressing in brown fat and white fat, thereby proving its importance in adipocyte differentiation [56].

The development of fatty liver disease correlates with lipid mobilization, hepatic metabolism of free fatty acids, IR, oxidative stress, and gluconeogenesis. Studies have shown that PPAR $\gamma$ directly participates in lipid metabolism, thereby affecting lipid synthesis, oxidation, and transport in the liver. Moreover, PPAR $\gamma$ regulates the metabolic processes, such as insulin resistance (IR), inflammation, and gluconeogenesis, indirectly affecting lipid metabolism in the liver (Appendix A, Table A1). As shown in Figure 1, PPAR $\gamma$ regulates different pathways through different factors, impacting on hepatic glucose and lipid metabolism. The following contents describe the molecular mechanisms and/or signaling pathways that are regulated by $\operatorname{PPAR} \gamma$, so as to reveal the dysregulation of lipid metabolism in hepatocytes and therefore contribution to fatty liver disease. It will be beneficial for understanding the pathogenesis of fatty liver disease in dairy cows and provide a molecular basis for the treatment and prediction of the disease. 


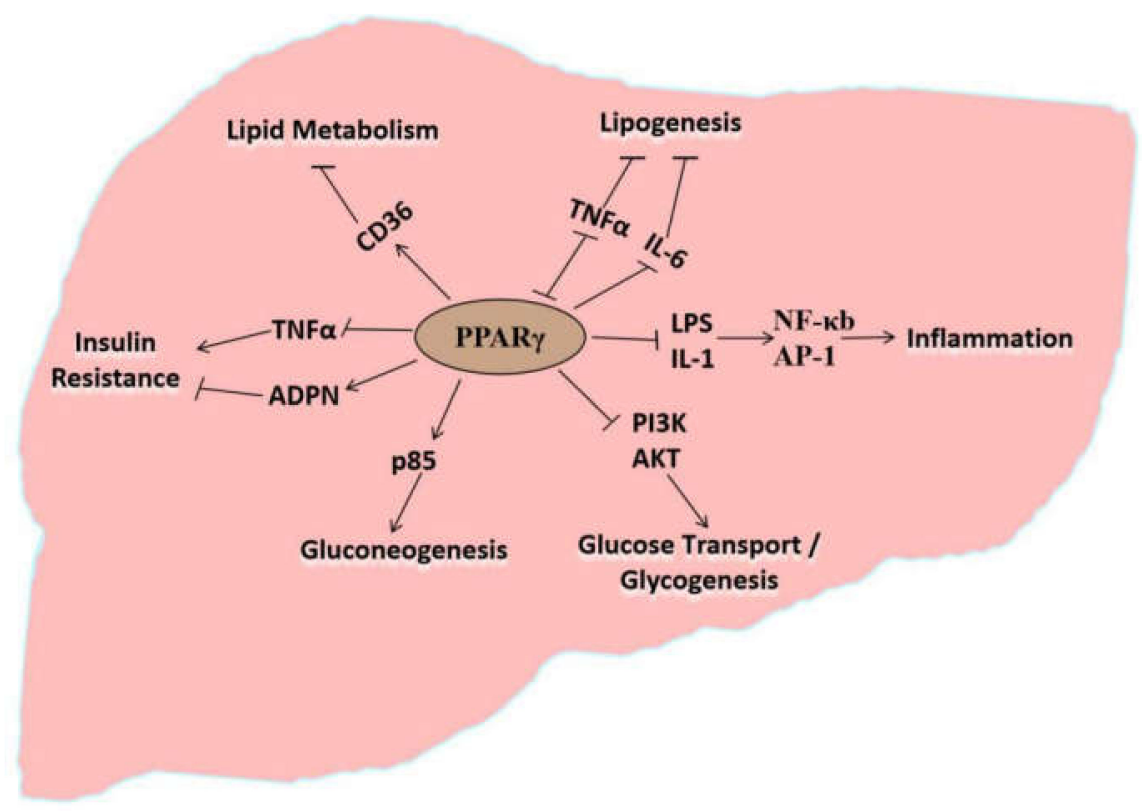

Figure 1. Peroxisome proliferator-activated receptor $\gamma(\operatorname{PPAR} \gamma)$ participates in regulation of liver associated biological processes through different signaling factors and/or cytokines. Arrows indicate positive regulation and blunt arrows indicate negative regulation.

\section{PPAR $\gamma$ Directly Regulates Lipid Metabolism in the Liver}

PPAR $\gamma$ regulates target gene expression in adipocytes, participating in adipocyte differentiation [52,57] and regulating lipid metabolism [57-59], and primarily regulates signal transduction in pancreatic islet cells, greatly contributing to the occurrence and development of NAFLD. In addition to its significance in adipocyte differentiation, PPAR $\gamma$ is crucial in mediating lipid oxidation and lipogenesis [60,61]. Leptin-deficient obese (ob/ob) mice with inhibited liver specific PPAR $\gamma$ exhibit significant alleviation of fat deposition in liver, but along with aggravated hyperglycemia and IR [62,63]. Deletion of PPAR $\gamma$ in hepatocytes and macrophages prevent mice from developing hepatic steatosis $[64,65]$. The expression of PPAR $\gamma$ and lipogenesis-related genes, such as the fatty acid transporter $C D 36$, are significantly elevated in the liver during hepatic steatosis, along with increased TAG level in the liver [66] (Figure 1). The above findings suggest that PPAR $\gamma$ activation promotes lipid deposition in the liver [67].

The downstream target of PPAR $\gamma, \mathrm{CD} 36$, is a scavenger receptor class B that is primarily involved in the membrane transport of medium and long chain fatty acids. In macrophages, PPAR $\gamma$ and RXR (retinoid $\mathrm{X}$ receptor) form a heterodimer that binds to the specific PPAR $\gamma$ response element located in the promoter region of $C D 36$ gene and therefore increases CD36 mRNA (messanger ribonuclei acid) level [68]. Compared to the mice fed with a normal diet, mice fed with high-fat diet after 4 weeks of administration showed significant upregulation of PPAR $\gamma 2$ and increased TAG content in hepatocytes. In contrast, silencing PPAR $\gamma 2$ using an adenoviral siRNA vector inhibits the expression of $C D 36$ and subsequently reduces TAG content in liver [69]. In experimental models without adipose tissues, liver PPAR $\gamma$ participates in lipid and glucose metabolism. However, in the presence of adipose tissues, liver PPAR $\gamma$ has a minimal effect on glucose metabolism in the liver [70], suggesting that PPAR $\gamma$ mainly regulates lipid metabolism in the liver.

The observations above indicate that PPAR $\gamma$ regulates the expression of the downstream target (CD36), thereby enabling TAG deposition and affecting lipid metabolism in the liver and plays a vital role in the occurrence of fatty liver disease (Wang et al., unpublished data; Figure 1). Our results also indicated that the downstream target genes of PPAR $\gamma$ were regulated by scaffold protein menin and $\mathrm{NAD}^{+}$(nicotinamide adenine dinucleotide)-dependent class III histone deacetylase sirtuin 1 (SIRT1) at the transcription level, affecting lipid deposition in hepatocytes (Li et al., unpublished data). 


\section{PPAR $\gamma$ Indirectly Participates in Lipid Metabolism via Lipid Oxidation}

Activated PPAR $\gamma$ regulates the expression of oxidative stress-related factors. After PPAR $\gamma$ ligand activation, PPAR/RXR undergoes conformational changes and associates with coactivators binding to PPAR $\gamma$ response elements locates in target genes, thereby regulating the transcription of these target genes [45,71,72]. Cytokines such as TNF $\alpha$ (tumor necrosis factor $\alpha$ ), IFN- $\gamma$ (interferon- $\gamma$ ), IL-1 (interleukin-1), IL-2 (interleukin-2), and IL-6 (interleukin-6) inhibit lipogenesis in adipose tissues. However, activated PPAR $\gamma$ can decreases cytokine levels, thereby promoting lipogenesis and causing inflammation reaction [73,74] (Figure 1). Activated PPAR $\gamma$ expression in macrophages is confirmed to play anti-inflammatory roles in humans and rodents [74,75]. Moreover, PPAR $\gamma$ ligands stimulate macrophage apoptosis [74,76,77]. Lipopolysaccharides are an important etiological factor for the systemic inflammatory response disease. PPAR $\gamma$ activation inhibits the activity of lipopolysaccharide and IL-1 by reducing DNA (deoxyribonucleic acid) binding and transcription by nuclear factor- $\mathrm{kB}$ $(\mathrm{NF} \kappa \mathrm{B})$, activator protein-1, and signal transducer and activator of transcription 1, thereby directly inhibiting the expression of pro-inflammatory genes and indirectly promoting liver lipogenesis resulting in excessive lipid accumulation in the liver [78-80]. PPAR $\gamma$ decreases the expression of inflammatory cytokines TNF $\alpha$ and IL-1, and therefore suppressing the inflammation-inducing effects and oxidative stress. In contrast, these inflammation factors may inhibit lipogenesis. Reducing the level of these inflammatory factors indirectly promotes lipogenesis and stimulates lipid deposition, causing the incidence of fatty liver disease.

\section{PPAR $\gamma$ Indirectly Participates in Lipid Metabolism via Insulin Resistance}

Insulin resistance (IR) refers to impaired normal physiological function of insulin, therefore the target organs have reduced sensitivity to insulin. Studies have shown that IR is the main cause of NAFLD [81,82]. As a result of IR, serum fatty acid levels are increased and produce damaging reactive oxygen species (ROS). Oxidative stress may be exacerbated further by ultrastructural mitochondrial lesions, which impair respiratory chain function. Insulin inhibits $\beta$-oxidation in the mitochondria through modifying the protein acetylation [83-85], resulting in the accumulation of lipids in hepatocytes.

A study found that individuals with PPAR $\gamma$ deletions suffer from early-onset type II diabetes accompanied with severe IR [50]. Adipocytokines, such as inflammatory factors (TNF- $\alpha$ and IL-6), released during obesity by adipose tissues affect host tissues and target organs (liver) and cause IR in the liver (Figure 1). Hence, PPAR $\gamma$ is an important candidate for IR suppression. Upon PPAR $\gamma$ activation by its ligand, insulin sensitivity of cells increases, promoting the expression of sterol regulatory element-binding protein-1, fatty acid-binding protein-4, and lipases in adipocytes, and increasing free fatty acid uptake and de novo synthesis of TAG in liver tissues [61,86,87].

Adiponectin (ADPN) is an endogenous bioactive protein that is secreted by adipocytes. ADPN is an insulin-sensitizing hormone that alleviates IR. PPAR $\gamma$ activation increases ADPN mRNA stability and promotes ADPN synthesis, stability, and release [88]. PPAR $\gamma$ also upregulates the expression of insulin-dependent glucose transporter 4 (GLUT4) and phosphoinositide 3-kinase (PI3K) in adipose and muscle tissues, induces the expression of casitas B-lineage lymphoma (CBLB) that participates in insulin signaling, and inhibits the expression of suppressor of cytokine signaling 3 that participates in IR to maintain insulin sensitivity in adipose tissues and skeletal muscles $[65,88-90]$. PPAR $\gamma$ regulates insulin signal transduction and the expression of ADPN and inflammatory proteins to modulate the degree of hepatic IR (Figure 1), playing an important regulatory role in the accumulation of TAG in the liver.

\section{PPAR $\gamma$ Indirectly Participates in Lipid Metabolism via Gluconeogenesis}

Gluconeogenesis is the process in which non-carbohydrate precursors are converted to glucose or glycogen. Diabetes and fatty liver disease involve gluconeogenesis and dysregulated glycogenolysis resulting in increased hepatic glucose output $[91,92]$. 
PPAR $\gamma$ is an important target for treating disorders involving lipid metabolism, IR, and gluconeogenesis $[82,86]$. A reduction in PPAR $\gamma$ expression in the liver increases the expression of hexokinase and reduces that of gluconeogenesis enzymes, such as phosphoenolpyruvate carboxykinase (PEPCK) and glucose-6-phosphatase (G6P), thereby inhibiting hepatic gluconeogenesis and deposition of TAG in the liver [93]. Activated PPAR $\gamma$ enhances the expression of the phosphoinositide 3-kinase subunit p85 and promotes hepatic gluconeogenesis (Figure 1) [94]. Activated PPAR $\gamma$ also increases the synthesis of glucagon, influx of amino acids into hepatocytes, and conversion to glucose via gluconeogenesis. Accordingly, PPAR $\gamma$ directly and indirectly regulates the expression of enzymes and proteins involved in hepatic gluconeogenesis. Thus, PPAR $\gamma$ is an important upstream regulator increasing the incidence of diabetes and fatty liver disease [95].

In summary, PPAR $\gamma$ is a transcription factor that regulates adipocyte differentiation, lipid accumulation, fatty acid oxidation and synthesis, oxidative stress, IR, and expression of the gluconeogenesis-related genes, therefore modulating the biological processes involved in hepatic lipid metabolism (Figure 1). Accordingly, PPAR $\gamma$ is an important protein that regulates the pathogenesis of NAFLD. Investigations on the agonists and antagonists of PPAR $\gamma$ might provide novel ideas for the development of drugs against NLFLD.

\section{Conclusions and Outlook}

NAFLD is a clinico-pathologically defined process associated with metabolic syndrome [23] and fundamentally pin-pointed to the pathogenesis of lipid metabolism, causing, for example, type II diabetes, obesity, either development of cardiovascular diseases or cirrhosis, and hepatocellular carcinoma (HCC), threatening the health of humans and animals. The disease is characterized histologically steatosis and other parenchymal changes, ranging from inflammation to hepatocyte apoptosis/necrosis to fibrosis. NAFLD has become a globally occurring chronic disease that threatens the health of both humans and animals $[20,21,96]$. However, there is no efficacious drug available that can directly be used to treat NAFLD. Cellular stress and immune reactions, as well as lipid metabolism, had been implicated in the pathogenesis of in animal NAFLD models [23]. There was ample evidence of the positive effects of dietary antioxidant polyphenols, carotenoids, and glucosinolates on the reversion of NAFLD [34,97], although the mechanism of their action was not yet fully elucidated. Discovery and revealing the mechanisms of the important regulatory factors/genes, such as PPAR $\gamma$, that regulate the pathogenesis of this disease is pertinent and imperative for preventing and treating fatty liver disease in humans and animals. Understanding the molecular mechanisms of the pathogenesis of fatty liver disease will further enhance our understanding of NAFLD, developing safer and effective therapeutics to prevent and/or treat fatty liver disease in humans and animals.

Fatty liver syndrome is a typical type of NAFLD frequently occurring in dairy cows in the perinatal period, caused by negative nutrient balance after calving. The fatty liver disease that occurs in dairy cows is a good animal model to reveal the pathology and pathogenesis of NAFLD. More recent study suggests that impaired hepatic mitochondrial function (such as protein lysine acetylation) is closely associated with fatty liver disease during early lactation in dairy cows [43,84]. Determining the crucial genetic factors, such as PPAR $\gamma$, will also provide essential clues in breeding improvement of fatty liver disease-resistant dairy cattle, eventually contributing to sustainable development of dairy industry.

Author Contributions: K.S., R.L., and Z.X. participated in the manuscript writing; R.L. and Z.X. contributed to the investigation of metabolic disorder in farms and analyzed the data; Q.Z. and K.S. led the core concept of the review; Q.Z. participated in content examination and discussion. All authors have read and agreed to the published version of the manuscript.

Funding: The work was supported by the Key Project of Agricultural Fine Breeding of Shandong Province (2019LZGC011, 2016LZGC030), National Natural Science Foundation of China (31402054) and Natural Science Foundation of Shandong Province (ZR2013CM013).

Acknowledgments: We thank Jinming Huang (Dairy Cattle Research Center, Shandong Academy of Agricultural Sciences), Yundong Gao and Jianbin Li (Shandong OX Liverstock Breeding Co., Ltd), Dongxiao Sun, Yachun 
Wang, and Ying Yu (China Agricultural University) for their assistance in investigations of fatty liver disease in commercial farms. We thank Elseviewer for its linguistic assistance during the preparation of this manuscript.

Conflicts of Interest: The authors declare that they have no conflicts of interest concerning this review.

\section{Appendix A}

Table A1. Biological processes associated with NAFLD are regulated by PPAR $\gamma$ through different signaling factors/proteins.

\begin{tabular}{|c|c|c|c|}
\hline \multirow{2}{*}{ Biological Processes } & \multicolumn{3}{|c|}{ Proteins or Signaling Factors That Interact with PPAR $\gamma$} \\
\hline & Protein Name & Protein Description or Abbreviation & References \\
\hline \multirow{3}{*}{ Lipid Metabolism } & NRF2 & Nuclear factor E2-related factor 2 & {$[45]$} \\
\hline & CD36 & Fatty acid translocase & [66] \\
\hline & $\mathrm{RXR}$ & Retinoid $\mathrm{X}$ receptor & [68] \\
\hline \multirow{10}{*}{ Oxidative Stress } & NRF2 & Nuclear factor E2-related factor 2 & {$[45,46]$} \\
\hline & IFN- $\gamma$ & Interferon- $\gamma$ & [74] \\
\hline & IL-1 & Interleukin-1 & [74] \\
\hline & IL-2 & Interleukin-2 & [74] \\
\hline & IL-6 & Interleukin-6 & [74] \\
\hline & LPS & Lipopolysaccharide & [78] \\
\hline & NF-kB & Nuclear factor kappa B & [79] \\
\hline & AP-1 & Activator protein-1 & [78] \\
\hline & STAT-1 & $\begin{array}{l}\text { Signal transducers and activators of } \\
\text { transcription } 1\end{array}$ & [78] \\
\hline & TNF- $\alpha$ & Tumor necrosis factor $\alpha$ & [86] \\
\hline \multirow{8}{*}{ Insulin Resistance } & SREBP-1 & $\begin{array}{l}\text { Sterol-regulatory element binding } \\
\text { protein-1 }\end{array}$ & [86] \\
\hline & TNF- $\alpha$ & Tumor necrosis factor $\alpha$ & [86] \\
\hline & ADPN & Adiponectin & [88] \\
\hline & CBLB & Casitas B-lineage lymphoma & [88] \\
\hline & SOCS3 & Suppressor of cytokine signaling 3 & [88] \\
\hline & AKT & Protein kinase B & [89] \\
\hline & GLUT4 & Glucose transport protein 4 & [89] \\
\hline & PI3K & Phosphoinositide 3-kinase & [89] \\
\hline \multirow{5}{*}{$\begin{array}{l}\text { Endoplasmic Reticulum } \\
\text { Stress }\end{array}$} & ATF6 & Activating Transcription Factor 6 & [29] \\
\hline & GRP78 & Glucose regulated protein 78 & [30] \\
\hline & IRE1 $\alpha$ & Inositol-requiring enzyme- $1 \alpha$ & [31] \\
\hline & NRF2 & Nuclear factor E2-related factor 2 & [45] \\
\hline & TNF- $\alpha$ & Tumor necrosis factor $\alpha$ & [86] \\
\hline \multirow{4}{*}{ Gluconeogenesis } & HK & Histinine kinase & [93] \\
\hline & PEPCK & Phosphoenolpyruvate carboxykinase & [93] \\
\hline & G6P & Glucose-6-phosphate & {$[93]$} \\
\hline & PI3K & Phosphoinositide 3-kinase & [94] \\
\hline
\end{tabular}

NAFLD, non-alcoholic fatty liver disease; PPAR $\gamma$, peroxisome proliferator-activated receptor $\gamma$. 


\section{References}

1. Shi, K.R.; Niu, F.; Zhang, Q.; Ning, C.; Yue, S.J.; Hu, C.Z.; Xu, Z.J.; Wang, S.X.; Li, R.R.; Hou, Q.L.; et al. Identification of whole-genome significant single nucleotide polymorphisms in candidate genes associated with serum biochemical traits in Chinese Holstein cattle. Fornt. Genet. 2020, 11, 163. [CrossRef]

2. Yan, Z.G.; Wang, Z.H.; Zhang, Q.; Yue, S.J.; Yin, B.; Jiang, Y.L.; Shi, K.R. Identification of whole-genome significant single nucleotide polymorphisms in candidate genes associated with body conformation traits in Chinese Holstein cattle. Anim Genet. 2020, 51, 141-152. [CrossRef]

3. Reid, I.M.; Rowlands, G.J.; Dew, A.M.; Collins, R.A.; Roberts, C.J.; Manston, R. The relationship between1 post-parturient fatty liver and blood composition in dairy cows. J. Agric. Sci.-Camb. 1983, 101, 473-480. [CrossRef]

4. Starke, A.; Schmidt, S.; Haudum, A.; Scholbach, T.; Wohlsein, P.; Beyerbach, M.; Rehage, J. Evaluation of portal blood flow using transcutaneous and intraoperative Doppler ultrasonography in dairy cows with fatty liver. J. Dairy Sci. 2011, 94, 2964-2971. [CrossRef] [PubMed]

5. Bradford, B.J.; Yuan, K.; Farney, J.K.; Mamedova, L.K.; Carpenter, A.J. Invited review: Inflammation during the transition to lactation: New adventures with an old flame. J. Dairy Sci. 2015, 98, 6631-6650. [CrossRef]

6. Godden, S.; Rapnicki, P.; Stewart, S.; Fetrow, J.; Johnson, A.; Bey, R.; Farnsworth, R. Effectiveness of an internal teat seal in the prevention of new intramammary infections during the dry and early-lactation periods in dairy cows when used with a dry cow intramammary antibiotic. J. Dairy Sci. 2003, 86, 3899-3911. [CrossRef]

7. Carvalho, M.R.; Peñagaricano, F.; Santos, J.E.P.; DeVries, T.J.; McBride, B.W.; Ribeiro, E.S. Long-term effects of postpartum clinical disease on milk production, reproduction, and culling of dairy cows. J. Dairy Sci. 2019, 102, 11701-11717. [CrossRef]

8. Quenon, J.; Ingrand, S.; Magne, M. Managing the transition from purebred to rotational crossbred dairy cattle herds: Three technical pathways from a retrospective case-study analysis. Animal 2020, 1, 1-11. [CrossRef] [PubMed]

9. Li, S.L.; Huang, W.M.; Tian, Y.J.; Cao, Z.J. Energy metabolism and its regulation of perinatal dairy cows. Prog. J. Nutr. 2012, 170-176.

10. Vries, A.B.; Huang, H.W.; Zou, Y.; Cao, Z.J. Economic benefit analysis of prolonging the service life of dairy cattle. China Dairy Cattle 2014, 12, 68-75.

11. Carpenter, A.J.; Ylioja, C.M.; Vargas, C.F.; Mamedova, L.K.; Mendonca, L.G.; Coetzee, J.F.; Hollis, L.C.; Gehring, R.; Bradford, B.J. Hot topic: Early postpartum treatment of commercial dairy cows with nonsteroidal antiinflammatory drugs increases whole-lactation milk yield. J. Dairy Sci. 2016, 99, 672-679. [CrossRef] [PubMed]

12. Yue, S.J.; Zhao, Y.Q.; Gu, X.R.; Yin, B.; Jiang, Y.L.; Wang, Z.H.; Shi, K.R. A genome-wide association study suggests new candidate genes for milk production traits in Chinese Holstein cattle. Anim. Genet. 2017, 48, 677-681. [CrossRef] [PubMed]

13. Koo, S.H. Nonalcoholic fatty liver disease: Molecular mechanisms for the hepatic steatosis. Clin. Mol. Hepatol. 2013, 19, 210-215. [CrossRef]

14. Katoh, N. Relevance of apolipoproteins in the development of fatty liver and fatty liver-related peripartum diseases in dairy cows. J. Vet. Med. Sci. 2002, 64, 293-307. [CrossRef]

15. Jorritsma, R.; Jorritsma, H.; Schukken, Y.H. Relationships between fatty liver and fertility and some periparturient diseases in commercial Dutch dairy herds. Theriogenology 2000, 54, 1065-1074. [CrossRef]

16. Hu, Z.Y.; Yin, Z.Y.; Lin, X.Y.; Yan, Z.G.; Wang, Z.H. Effects of feeding fatty acid calcium and the interaction of forage quality on production performance and biochemical indexes in early lactation cow. J. Anim. Physiol. Anim. Nutr. 2015, 99, 899-904. [CrossRef]

17. Farid, A.S.; Honkawa, F.; Fath, E.M. Serum paraoxonase-1 as biomarker for improved diagnosis of fatty liver in dairy cows. BMC Vet. Res. 2013, 9, 73. [CrossRef]

18. Pullen, D.L.; Liesman, J.S.; Emery, R.S. A species comparison of liver slice synthesis and secretion of triacylglycerol from nonesterified fatty acids in media. J. Anim. Sci. 1990, 68, 1395-1399. [CrossRef]

19. Nasr, P.; Ignatova, S.; Kechagias, S.; Ekstedt, M. Natural history of nonalcoholic fatty liver diasease: A prospective follow-up study with serial biopsies. Hepatol. Res. 2018, 2, 199-210. 
20. Demir, M.; Lang, S.; Steffen, H.M. Nonalcoholic fatty liver disease-Current status and future directions. J. Digest Dis. 2015, 16, 541-557. [CrossRef]

21. Du, H.T.; Wang, C.Y.; Wang, X.P.; Ma, M.W.; Li, F.C. The effects of dietary $\alpha$-linolenic acid on growth performance, meat quality, fatty acid composition, and liver relative enzyme mRNA expression of growing meat rabbits. J. Anim. Feed Sci. 2013, 22, 122-129. [CrossRef]

22. Bellentani, S. The epidemiology of non-alcoholic fatty liver disease. Liver Int. 2017, 37, 81-84. [CrossRef] [PubMed]

23. Tiniakos, D.G.; Vos, M.B.; Brunt, E.M. Nonalcoholic fatty liver disease: Pathology and pathogenesis. Annu. Rev. Pathol.-Mech. 2010, 5, 145-171. [CrossRef]

24. Day, C.P. Non-alcoholic fatty liver disease: A massive problem. J. Clin. Med. 2011, 11, 176-178. [CrossRef]

25. Clavien, P.; Camargo, C.; Gorczynski, R.; Washington, M.; Levy, G.; Langer, B.; Greig, P. Reasctant cytokines and neutrophil adhesion after warm ischemia in cirrhotic and noncirrhotic human livers. Hepatology 1996, 23, 1456. [CrossRef] [PubMed]

26. Duvnjak, M.; Lerotić, I.; Barsić, N.; Tomasić, V.; Virović, J.L.; Velagić, V. Pathogenesis and management issues for non-alcoholic fatty liver disease. World J. Gastroenterol. 2007, 13, 4539-4550. [CrossRef]

27. Jou, J.; Choi, S.S.; Diehl, A.M. Mechanisms of disease progression in nonalcoholic fatty liver disease. Semin. Liver Dis. 2008, 28, 370-379. [CrossRef]

28. Dela Peña, A.; Leclercq, I.; Field, J.; George, J.; Jones, B.; Farrell, G. NF-kappaB activation, rather than TNF, mediates hepatic inflammation in a murine dietary model of steatohepatitis. Gastroenterology 2005, 129, 1663-1674. [CrossRef] [PubMed]

29. Winnay, J.N.; Boucher, J.; Mori, M.A.; Ueki, K.; Kahn, C.R. A regulatory subunit of phosphoinositide 3-kinaseincreases the nuclear accumulation of X-box binding protein-1 to modulate the unfolded protein response. Nat. Med. 2010, 16, 438-445. [CrossRef]

30. Bjornsson, E.; Angulo, P. Non-alcoholic fatty liver disease. Gastroenterology 2007, 142, 1023-1130. [CrossRef]

31. Wang, S.; Chen, Z.; Lam, V.; Han, J.; Hassler, J.; Finck, B.N.; Davidson, N.O.; Kaufman, R.J. IRE1 $\alpha-X B P 1 S$ induces PDI expression to increase MTP activity for hepatic VLDL assembly and lipid homeostasis. Cell Metabolism. 2012, 16, 473-486. [CrossRef]

32. Bartlett, P.J.; Gaspers, L.D.; Pierobon, N.; Thomas, A.P. Calcium-dependent regulation of glucose homeostasis in the liver. Cell Calcium. 2014, 55, 306-316. [CrossRef]

33. Tacer, K.F.; Rozman, D. Nonalcoholic fatty liver disease: Focus on lipoprotein and lipid deregulation. J. Lipid Res. 2011, 2011, 783976.

34. Ferramosca, A.D.; Giacomo, M.; Zara, V. Antioxidant dietary approach in treatment of fatty liver: New insight and updates. World J. Gastroenterol. 2017, 23, 4146-4157. [CrossRef]

35. Adams, L.A.; Angulo, P.; Lindor, K.D. Nonalcoholic fatty liver disease. Can. Med. Assoc. J. 2005, 172, 899-905. [CrossRef] [PubMed]

36. Dowman, J.K.; Tomlinson, J.W.; Newsome, P.N. Pathogenesis of non-alcoholic fatty liver disease. QJM 2010, 103, 71-83. [CrossRef]

37. Liu, L.; Fu, C.; Li, F. Acetate affects the process of lipid metabolism in rabbit liver, skeletal muscle and adipose tissue. Animals 2019, 9, 799. [CrossRef]

38. Lu, W.J.; Liu, X.F.; Zhao, X.C.; Guo, X.Q.; Kang, M.J.; Xu, B.H. Identification and antioxidant characterisation of thioredoxin-like1 from Apis cerana cerana. Apidologie 2012, 43, 737-752. [CrossRef]

39. Rotman, Y.; Sanyal, A.J. Current and upcoming pharmacotherapy for non-alcoholic fatty liver disease. Gut 2017, 66, 180-190. [CrossRef] [PubMed]

40. Younossi, Z.M.; Loomba, R.; Rinella, A.E.; Bugianesi, E.; Marchesini, G.; Neuschwander-Tetri, B.A.; Serfaty, L.; Negro, F.; Caldwell, S.H.; Ratziu, V.; et al. Current and future therapeutic regimens for nonalcoholic fatty liver disease and nonalcoholic steatohepatitis. Hepatology 2018, 68, 361-371. [CrossRef] [PubMed]

41. Machado, M.; Cortez-Pinto, H. Non-alcoholic fatty liver disease and insulin resistance. Eur. J. Gastroenterol. Hepat. 2005, 17, 823-826. [CrossRef]

42. Fraenkel, E.; Lazurova, I.; Feher, J. Role of lipid peroxidation in non-alcoholic steatohepatitis. Orvosi Hetilap. 2004, 145, 611-618. [PubMed]

43. He, X.W.; Gao, J.; Hou, H.; Qi, Z.; Chen, H.; Zhang, X.X. Inhibition of mitochondrial fatty acid oxidation contributes to development of nonalcoholic fatty acid liver disease induced by environmental cadmium exposure. Environ. Sci. Technol. 2019, 53, 13992-14000. [CrossRef] 
44. Wang, S.; Dougherty, E.J.; Danner, R.L. PPAR $\gamma$ signaling and emerging opportunities for improved therapeutics. Pharmacol. Res. 2016, 111, 76-85. [CrossRef] [PubMed]

45. Feng, X.; Yu, W.; Li, X.; Zhou, F.; Zhang, W.; Shen, Q.; Li, J.; Zhang, C.; Shen, P. Apigenin, a modulator of PPARgamma, attenuates HFD-induced NAFLD by regulating hepatocyte lipid metabolism and oxidative stress via Nrf2 activation. Biochem. Pharmacol. 2017, 136, 136-149. [CrossRef]

46. Cheng, Q.; Jiang, S.; Huang, L.; Wang, Y.; Yang, W.; Yang, Z.; Ge, J. Effects of zearalenone-induced oxidative stress and Keap1-Nrf2 signaling pathway-related gene expression in the ileum and mesenteric lymph nodes of post-weaning gilts. Toxicology 2020, 429, 152337. [CrossRef]

47. Zhu, Y.; Kan, L.; Qi, C.; Kanwar, Y.S.; Yeldandi, A.V.; Rao, M.S.; Reddy, J.K. Isolation and characterization of peroxisome proliferator-activated receptor (PPAR) interacting protein (PRIP) as a coactivator for PPAR. J. Biol. Chem. 2020, 275, 13510-13516. [CrossRef]

48. Latruffe, N.; Vamecq, J. Peroxisome proliferators and peroxisome proliferator activated receptors (PPARs) as regulators of lipid metabolism. Biochimie 1997, 79, 81-94. [CrossRef]

49. Mano, H.; Kimura, C.; Fujisawa, Y.; Kameda, T.; Watanabe-Mano, M.; Kaneko, H.; Kumegawa, M. Cloning and function of rabbit peroxisome proliferator-activated receptor delta/beta in mature osteoclasts. J. Biol. Chem. 2020, 275, 8126-8132. [CrossRef] [PubMed]

50. Vamecq, J.; Latruffe, N. Medical of significance peroxisome proliferator-activated receptors. Lancet 1999, 354, 141-148. [CrossRef]

51. Fu, C.Y.; Liu, L.; Li, F.C. Acetate alters the process of lipid metabolism in rabbits. Animal 2018, 12, 1895-1902. [CrossRef] [PubMed]

52. Guan, Y.; Zhang, Y.; Breyer, M.D. The Role of PPARs in the Transcriptional Control of Cellular Processes. Drug News Perspect. 2002, 15, 147-154. [CrossRef]

53. Bordji, K.; Grillasca, J.P.; Gouze, J.N.; Magdalou, J.; Schohn, H.; Keller, J.M.; Terlain, B. Evidence for the presence of peroxisome proliferator-activated receptor (PPAR) alpha and gamma and retinoid $\mathrm{Z}$ receptor in cartilage. J. Biol. Chem. 2000, 275, 12243-12250. [CrossRef] [PubMed]

54. Grygiel-Gorniak, B. Peroxisome proliferator-activated receptors and their ligands: Nutritional and clinical implications a review. J. Nutr. 2014, 13, 13-17. [CrossRef] [PubMed]

55. Gupta, M.; Mahajan, V.K.; Mehta, K.S.; Chauhan, P.S.; Rawat, R. Peroxisome proliferator-activated receptors (PPARs) and PPAR agonists: The "future" in dermatology therapeutics? Arch. Dermatol. Res. 2015, 307, 767-780. [CrossRef]

56. Cui, J.X.; Zeng, Y.Q.; Wang, H.; Chen, W.; Du, J.F.; Chen, Q.M.; Hu, Y.X.; Yang, L. The effects of DGAT1 and DGAT2 mRNA expression on fat deposition in fatty and lean breeds of pig. Livest Sci. 2011, 140, 292-296. [CrossRef]

57. Wang, H.; Wang, J.; Yang, D.D.; Liu, Z.L.; Zeng, Y.Q.; Chen, W. Expression of lipid metabolism genes provides new insights into intramuscular fat deposition in Laiwu pigs. Asian Aystral. J. Anim. 2020, 33, 390-397. [CrossRef]

58. Filip-Ciubotaru, F.; Foia, L.; Manciuc, C.; Grigore, C. PPARs: Structure, mechanisms of action and control. Note I. Rev. Med. Chir. Soc. Med. Nat. Iasi. 2011, 115, 477-484.

59. Yu, X.L.; Guo, X.Q.; Kang, M.J.; Liu, L.; Xu, B.H. Identification and expression analysis of a putative fatty acid-binding protein gene in the Asian honeybee, Apis cerana cerana. J. Insect Sci. 2013, 13, 101. [CrossRef]

60. Kurosaki, E.; Nakano, R.; Shimaya, A.; Yoshida, S.; Ida, M.; Suzuki, T.; Shibasaki, M.; Shikama, H. Differential effects of YM440 a hypoglycemic agent on binding to a peroxisome proliferator-activated receptor gamma and its transactivation. Biochem. Pharmacol. 2003, 65, 795-805. [CrossRef]

61. Wang, Y.; He, J.Z.; Yang, W.X.; Muhantay, G.; Chen, Y.; Xing, J.M.; Liu, J.Z. Correlation between heart-type fatty acid-binding protein gene polymorphism and mrna expression with intramuscular fat in baicheng-oil chicken. Asian Austral. J. Anim. 2015, 28, 1380. [CrossRef]

62. Liu, L.; Zhu, L. Effect of $24 \mathrm{~h}$ fasting on gene expression of AMPK, appetite regulation peptides and lipometabolism related factors in the hypothalamus of broiler chicks. Asian Austral. J. Anim. 2012, 25, 1300-1308. [CrossRef] [PubMed]

63. Zhang, X.; Ji, R.; Sun, H.; Peng, J.; Ma, X.; Wang, C.; Fu, Y.; Bao, L.; Jin, Y. Scutellarin ameliorates nonalcoholic fatty liver disease through the PPAR $\gamma /$ PGC-1 $\alpha$-Nrf2 pathway. Free Radical. Res. 2018, 52, 198-211. [CrossRef]

64. Moran-Salvador, E. Role for PPARgamma in obesity-induced hepatic steatosis as determined by hepatocyteand macrophage-specific conditional knockouts. Faseb. J. 2011, 25, 2538-2550. [CrossRef] 
65. Liu, L.; Xu, S.H.; Wang, X.J.; Jiao, H.C.; Lin, H. Peripheral insulin doesn't alter appetite of broiler chicks. Asian Austral. J. Anim. 2016, 29, 1294-1299. [CrossRef]

66. Rangwala, S.M.; Lazar, M.A. Peroxisome proliferator-activated receptor gamma in diabetes and metabolism. Trends Pharmacol. Sci. 2004, 25, 331-336. [CrossRef]

67. Larter, C.Z.; Yeh, M.M.; Williams, J.; Bell-Anderson, K.S.; Farrell, G.C. MCD-induced steatohepatitis is associated with hepatic adiponectin resistance and adipogenic transformation of hepatocytes. J. Hepatol. 2008, 49, 407-416. [CrossRef] [PubMed]

68. Nagy, L.; Tontonoz, P.; Alvarez, J.G.; Chen, H.; Evans, R.M. Oxidized LDL regulates macrophage gene expression through ligand activation of PPARgamma. Cell 1998, 93, 229-240. [CrossRef]

69. Yamazaki, T.; Shiraishi, S.; Kishimoto, K.; Miura, S.; Ezaki, O. An increase in liver PPARgamma2 is an initial event to induce fatty liver in response to a diet high in butter: PPARgamma2 knockdown improves fatty liver induced by high-saturated fat. J. Nutr. Biochem. 2011, 22, 543-553. [CrossRef]

70. Gavrilova, O.; Haluzik, M.; Matsusue, K.; Cutson, J.J.; Johnson, L.; Dietz, K.R.; Nicol, C.J.; Vinson, C.; Gonzalez, F.J.; Reitman, M.L. Liver peroxisome proliferator-activated receptor gamma contributes to hepatic steatosis, triglyceride clearance, and regulation of body fat mass. J. Biol. Chem. 2003, 278, 34268-34276. [CrossRef]

71. Yan, H.R.; Meng, F.; Jia, H.H.; Guo, X.Q.; Xu, B.H. The identification and oxidative stress response of a zeta class glutathione s-transferase (GSTZ1) gene from apis cerana cerana. J. Insect Physiol. 2012, 58, 782-791. [CrossRef] [PubMed]

72. Dubaisi, S.; Fang, H.; Kocarek, T.A. Transcriptional regulation of human cytosolic sulfotransferase 1C3 by peroxisome proliferator-activated receptor gamma in LS180 human colorectal adenocarcinoma cells. Mol. Pharmacol. 2016, 90, 562-569. [CrossRef] [PubMed]

73. Liu, L.; Li, H.P.; Li, X.L.; Jiao, H.C.; Lin, H.; Ardashir, S.; Wang, Y.F.; Song, Z.G. Effects of acute heat stress on gene expression of brain-gut neuropeptides in broiler chickens (Gallus gallus domesticus). Anim. Sci. J. 2013, 91, 5194-5201.

74. Khazaei, M. Effect of peroxisome proliferator-activated receptor gamma on inflammatory markers. $A R Y A$ Atheroscler 2015, 11, 261-262.

75. Liu, L.; Fu, C.; Li, F.C. Dietary niacin supplementation suppressed hepatic lipid accumulation in rabbits. Asian Austral. J. Anim. 2016, 29, 1748-1755. [CrossRef]

76. Dong, X.S.; Zhai, R.N.; Liu, Z.L.; Lin, X.Y.; Wang, Z.H.; Hu, Z.Y. The effect of intravenous infusions of glutamine on duodenal cell autophagy and apoptosis in early-weaned calves. Animals 2019, 9, 404. [CrossRef]

77. Zhai, R.N.; Dong, X.S.; Feng, L.; Li, S.L.; Hu, Z.Y. The effect of heat stress on autophagy and apotosis of rumen, abomasum, duodenum, liver and kidney cells in calves. Animals 2019, 9, 85. [CrossRef] [PubMed]

78. Ricote, M.; Li, A.C.; Willson, T.M.; Kelly, C.J.; Glass, C.K. The peroxisome proliferator-activated receptor-gamma is a negative regulator of macrophage activation. Nature 1998, 391, 79-82. [CrossRef]

79. Genini, D.; Carbone, G.M.; Catapano, C.V. Multiple interactions between peroxisome proliferators-activated receptors and the ubiquitin-proteasome system and implications for cancer pathogenesis. PPAR Res. 2008, 2008, 195065. [CrossRef]

80. Li, R.G.; Wang, X.P.; Wang, C.Y.; Ma, M.W.; Li, F.C. Growth performance, meat quality and fatty acid metabolism response of growing meat rabbits to dietary linoleic acid. Asian Austral. J. Anim. 2012, 25, 1169-1177. [CrossRef]

81. Liu, L.; Wang, X.J.; Jiao, H.C.; Zhao, J.P.; Lin, H. Glucocorticoids inhibited hypothalamic target of rapamycin in high fat diet-fed chicks. Poultry Sci. 2015, 94, 2221-2227. [CrossRef]

82. Yang, Z.; Zhang, H.; Niu, Y.; Zhang, W.; Zhu, L.; Li, X.; Lu, S.; Fan, J.; Li, X.; Ning, G.; et al. Circulating periostin in relation to insulin resistance and nonalcoholic fatty liver disease among overweight and obese subjects. Sci. Rep. UK 2016, 6, 37886. [CrossRef] [PubMed]

83. Iyer, A.; Fairlie, D.P.; Brown, L. Lysine acetylation in obesity, diabetes and metabolic disease. Immunol. Cell Biol. 2012, 90, 39-46. [CrossRef]

84. Garcia-Roche, M.; Casal, A.; Mattiauda, D.A.; Ceriani, M.; Jasinsky, A.; Mastrogiovanni, M.; Trostchansky, A.; Carriquiry, M.; Cassina, A.; Quijiano, C. Impaired hepatic mitochondrial function during early lactation in dairy cows: Association with protein lysine acetylation. PLoS ONE 2019, 14, e0213780. [CrossRef] [PubMed] 
85. Zhang, Y.Q.; Zhou, F.Y.; Bai, M.Y.; Liu, Y.; Zhang, L.; Zhu, Q.; Bi, Y.; Ning, G.; Zhou, L.; Wang, X. The pivotal role of protein acetylation in linking glucose and fatty acid metabolism to $\beta$-cell function. Cell Death Dis. 2019, 10, 66. [CrossRef] [PubMed]

86. Lalloyer, F.; Staels, B. Fibrates, glitazones, and peroxisome proliferator-activated receptors. Arterioscl. Throm. Vas. 2010, 30, 894-899. [CrossRef] [PubMed]

87. Yuan, X.J. Expression of androgen receptor and estrogen receptor-alpha in the developing pituitary gland of male sheep lamb. Anim. Reprod Sci. 2011, 127, 164-168.

88. Shi, H.; Cave, B.; Inouye, K.; Bjorbaek, C.; Flier, J.S. Overexpression of suppressor of cytokine signaling 3 in adipose tissue causes local but not systemic insulin resistance. Diabetes 2006, 55, 699-707. [CrossRef]

89. Armoni, M.; Kritz, N.; Harel, C.; Bar-Yoseph, F.; Chen, H.; Quon, M.J.; Karnieli, E. Peroxisome proliferator-activated receptor-gamma represses GLUT4 promoter activity in primary adipocytes, and rosiglitazone alleviates this effect. J. Biol. Chem. 2003, 278, 30614-30623. [CrossRef]

90. Yang, L.J.; Zhou, M.; Huang, L.B.; Yang, W.R.; Yang, Z.B.; Jiang, S.Z.; Ge, J.S. Zearalenone promotes follicle growth through modulation of Wnt-1/ $\beta$-catenin signaling pathway and expression of estrogen receptor genes in ovaries of post-weaning piglets. J. Agr. Food Chem. 2018, 66, 7899-7906. [CrossRef]

91. Moller, D.E. New drug targets for type 2 diabetes and the metabolic syndrome. Nature 2011, 414, 821-827. [CrossRef] [PubMed]

92. Jiang, F.G.; Lin, X.Y.; Yan, Z.G.; Hu, Z.Y.; Wang, Y.; Wang, Z.H. Effects of forage source and particle size on feed sorting, milk production and nutrient digestibility in lactating dairy cows. J. Anim. Physiol. Anim. Nutr. 2018, 102, 1472-1481. [CrossRef]

93. Goto, M.; Yoshioka, T.; Battelino, T.; Ravindranath, T.; Zeller, W.P. TNFalpha decreases gluconeogenesis in hepatocytes isolated from 10-day-old rats. Pediatr. Res. 2001, 49, 552-557. [CrossRef] [PubMed]

94. Bo, Q.F.; Sun, X.M.; Liu, J.; Sui, X.M.; Li, G.X. Antitumor action of the peroxisome proliferator-activated receptor- $\gamma$ agonist rosiglitazone in hepatocellular carcinoma. Oncol. Lett. 2015, 10, 3554. [CrossRef]

95. Tong, E.K.; England, L.; Glantz, S.A. Changing conclusions on secondhand smoke in a sudden infant death syndrome review funded by the tobacco industry. Pediatrics 2005, 115, 356-366. [CrossRef]

96. Lou, X.M.; Li, J.; Zhang, X.X.; Wang, J.M.; Wang, C.F. Variations in fatty acid composition of Laoshan goat milk from partum to 135 days postpartum. Anim. Sci. J. 2018, 89, 1628-1638. [CrossRef] [PubMed]

97. Anania, C.; Perla, F.M.; Olivero, F.; Pacifico, L.; Chiesa, C. Mediterranean diet and nonalcoholic fatty liver disease. World J. Gastroenterol. 2018, 24, 2083-2094. [CrossRef] 